\title{
The first sport injuries in the history of medicine
}

Nikitas N. Nomikos', George N. Nomikos², Konstantinos S. Nikolopoulos², Demetrios S. Korres²

${ }^{1}$ Faculty of Physical Education and Sports Science, Athens, Greece

${ }^{2}$ First Department of Orthopaedics, Athens University Medical School, Athens, Greece

Submitted: 28 April 2009

Accepted: 20 May 2009

Arch Med Sci 2010; 6, 1: 1-3

DOI 10.5114/aoms.2010.13498

Copyright (C 2010 Termedia \& Banach

\section{Abstract}

Medical science is as old as human history and the need for disease treatment. Archivists, researchers and historians are collaborating in the project to preserve the documentary inheritance and make the medical science useful to the public. This research aims to identify and analyze the first registered sport injuries in the history of medicine. After a review of the literature, the Homeric epics, the texts of the first historical period of ancient Greece, were identified and analyzed as the texts which contain the first sport injuries in world history.

Key words: sport injuries, boxing, trauma, medicine.

The political significance of the ancient Greek games contributed significantly to complete mobilization of mental and bodily forces of the competitors in achieving high athletic performance. The desire for victory and fame was the primary objective for competition, and led to the creation of elite athletic events. This tension in combination with the lack of detailed rules was the main cause of sport injury in almost all forms of sporting activity.

The present study was focused only on the Homeric epics: the Iliad (Trojan War) and the Odyssey (Odysseus' return to Ithaca).

Homer is traditionally believed to be the author of the ancient Greek epic poems the lliad and the Odyssey. The exact publication date of these works cannot be determined with absolute accuracy. Today the hymns are considered to be later works but many still regard Homer as the author of the epics. The ancient Greeks generally believed that Homer was a historical individual, but some modern scholars are more sceptical about this theory: G. S. Kirk commented that "Antiquity knew nothing definite about the life and personality of Homer" [1]. The historian Herodotus said that Homer lived 400 years before his own time, which would place him at around $850 \mathrm{BC}$ [2]. According to the classicist and cultural historian Barbara Graziosi other ancient sources gave dates much closer to the supposed time of the Trojan War [3]. Alexander J. Young supports the hypothesis that the reports which are cited in book 23 of the lliad in C rhapsody were written to prehistoric times [4]. The truth is that the actual time of writing of Homer's epics cannot be determined accurately and the exact date is still a subject of historical research.

Homer in the description of the boxing match between Epeous and Euryalus characterizes the boxing game as painful: " $\pi \nu \gamma \mu \alpha \chi i \eta \zeta$ ' $\alpha \lambda \varepsilon \gamma \varepsilon i \tilde{\eta} \zeta$ $\theta \tilde{\eta} \kappa \varepsilon v$ ' $\alpha \varepsilon \theta \lambda \alpha$ " [5]. Then he cites a number of boxing injuries. In particular: "Let the man who is to have the cup come hither, for none but myself will take the mule. I am the best boxer of all here present, and none can beat
Corresponding author:

Nikitas N. Nomikos, PhD Athens University Medical and Sports Science School 23 Konstantinou Prifti Street Peania 19002, Athens, Greece Phone: +30-2110-100336, +30-6932993277 E-mail: nnomikos@phyed.duth.gr 
me. Is it not enough that I should fall short of you in actual fighting? Still, no man can be good at everything. I tell you plainly, and it shall come true; if any man will box with me I will bruise his body and break his bones; therefore let his friends stay here in a body and be at hand to take him away when I have done with him. They all held their peace, and no man rose save Euryalus son of Mecisteus, who was son of Talaus. [...] The son of Tydeus was Euryalus's second, cheering him on and hoping heartily that he would win. First he put a waistband round him and then he gave him some well-cut thongs of ox-hide; the two men being now girt went into the middle of the ring, and immediately fell to; heavily indeed did they punish one another and lay about them with their brawny fists. One could hear the horrid crashing of their jaws, and they sweated from every pore of their skin. Presently Epeus came on and gave Euryalus a blow on the jaw as he was looking round; Euryalus could not keep his legs; they gave way under him in a moment and he sprang up with a bound, as a fish leaps into the air near some shore that is all bestrewn with sea-wrack, when Boreas furs the top of the waves, and then falls back into deep water [6]. The intensity of the fight that followed is such that Epeus says: "I will bruise his body and break his bones" [7]. During the battle Euryalus accepts such a blow to the cheek that he could not stand upright for long. The speed of the blow was such that the movement of the athlete was likened to that of a fish [8].

Homer then says: "But noble Epeus caught hold of him and raised him up; his comrades also came round him and led him from the ring, unsteady in his gait, his head hanging on one side, and spitting great clots of gore. They set him down in a swoon and then went to fetch the double cup" [9]. Euryalus, who was defeated and tired, had haemoptysis. The spitting blood probably comes from abnormal teeth movements or broken teeth, or from breakage of the soft tissue and skin in the oral region. It is likely that the haemoptysis in this incident comes from skinning the surface of the epithelial tissue of the mouth, because of friction from the hard surface of the dorsal metacarpal (punch).

Boxing was one of the most dangerous games. References of the following authors are characteristic of the injuries caused during participation in boxing matches in antiquity. Philostratus reports that “...once the fighting time comes, the boxer will get wounded and will cause wounds..." [10]. The great doctor and philosopher Galen, referring to elite athletes of boxing, says that "...when the athletes grow old, they creep, wrinkle and squint due to the severe blows; their eyes fill with catarrhal liquids, their teeth fall, and their bones become porotic and break easily" [11].
Artemidoros says that "...if you dream of boxing, this, apart from shame, also means trouble, because the person becomes ugly and bleeds" [12].

Homer mentions another incident of injury (lliad), in chariot races organized by Achilles (funeral games) to honour the dead Patroclus: "Minerva saw the trick which Apollo had played on the son of Tydeus, so she brought him his whip and put spirit into his horses; moreover she went after the son of Admetus in a rage and broke his yoke for him; the mares went one to one side of the course, and the other to the other, and the pole was broken against the ground. Eumelus was thrown from his chariot close to the wheel; his elbows, mouth, and nostrils were all torn, and his forehead was bruised above his eyebrows; his eyes filled with tears and he could find no utterance" [13].

This passage contains the earliest reference of sport injury (in a chariot race) in sport history. Difros in the lliad is the war chariot-wheel [14]. The chariot does not resist the high mechanical stress which leads it to open in two and Eumelus to fall to the ground and avoid more serious injury, with mere scratches on the elbows, mouth and nose. Also, Eumelus suffered trauma (rhexis of the continuity of the skin) in the frontal region and the eyebrows.

Furthermore, in the Odyssey Homer refers to a boxing match between Irus and Odysseus. This battle took place not in an official match, but it was informal and the audience were mainly the suitors of Penelope. Specifically: "Then they began to fight, and Irus hit Odysseus on the right shoulder; but Odysseus gave Irus a blow on the neck under the ear that broke in the bones of his skull, and the blood came gushing out of his mouth; he fell groaning in the dust, gnashing his teeth and kicking on the ground, but the suitors threw up their hands and nearly died of laughter, as Odysseus caught hold of him by the foot and dragged him into the outer court as far as the gate-house" [15]. In this informal contest, a significant sport injury is caused. Odysseus makes a blow in the area under the acoustic source (temple bone) and perhaps in the mandible. The technique of the attack which is combined with the high speed of the blow results in severe trauma: fractures " $\varepsilon \theta \lambda \alpha \sigma \varepsilon v$ " in the affected area and haemoptysis. This incident, apart from the fact that the Homeric epics exist between historical reality and myth, indicates the severity of the lesions introduced by the commission of boxing matches in antiquity.

The Homeric epics, the Iliad (Trojan War) and the Odyssey (Odysseus' return to Ithaca), are the oldest texts which contained references to sport activity [16]. Maxillofacial injuries occurred in the boxing match between Epeus and Euryalus (Iliad) [17]. During the battle Euryalus accepts such a blow to the cheek that he suffers haemoptysis. The spitting 
blood probably comes from mouth or teeth trauma. The hard surface of the dorsal metacarpal (punch) skinned the surface of the epithelial tissue of the mouth and caused haemorrhage. The haemorrhage that Homer mentions is likely to have resulted from teeth fracture or abnormal teeth movement.

Other maxillofacial injuries were found in funeral games in honour of the dead Patroclus, in which Eumelus due to his drop to the ground suffered scratches to the upper limbs and face (Iliad) [18]. Furthermore, with the above-mentioned traumas Eumelus suffered fission of the continuity of the skin in the frontal region and the eyebrows. Odysseus during a boxing match caused a fracture in the temple region of his opponent with haemoptysis (Odyssey) [19]. The high technique of the blow combined with the hard surface of the fist resulted in fractures in the temple bone and haemoptysis. Such injuries (maxillofacial) were common since blows to the head and face were permitted [20]. The fist (metacarpals) during a boxing match acquires extreme kinetic energy and if the athlete is not wearing a head helmet, a teeth or a nose fracture is possible. This is the main reason that in modern amateur boxing the head helmet is obligatory.

We cannot know for certain whether Homer's work was based on true history, but archaeologists have established and confirmed the main parts of the story: the Trojan War, ancient Mycenae, Agamemnon's tomb and the destroyed Troy. Heinrich Schliemann, the German archaeologist, first excavated in 1874 the site of Mycenae and also discovered the ruins of Troy. Furthermore, the way that Homer describes and analyses the conducted traumas indicates that the poet had attended ancient games or known the mechanism of generation of sport trauma. According to the above, we come to the conclusion that the Homeric epics likely contain the first recorded sport injuries in the history of medicine.

\section{References}

1. Kirk GS. The Iliad: a commentary. Vol. 1. Cambridge.

2. Herodotus 2.53 .

3. Graziosi B. The Invention of Homer. Cambridge 2002; $98-$ 101.

4. Young AJ Jr. Lets take our lessons from the ancient trainers. Proceedings from International Olympic Academy $13^{\text {th }}$ session 1973; 106.

5. Homer. lliad $\psi^{\prime} 655$.

6. Homer. lliad $\psi^{\prime}$ 669-93.

7. Homer. lliad $\psi^{\prime} 675$.

8. Homer. Iliad $\psi^{\prime} 693$.

9. Homer. lliad $\psi^{\prime}$ 694-9.

10. Philostratus, Gymnastics, 11

11. Galen. Protreptic about medicine, 11.

12. Artemidoros. Onirokritica, A, 61.

13. Homer. lliad $\psi^{\prime}$ 392-397.
14. Henry G. Liddell and Robert Scott. Dictionary of the Greek Language. J. Sideris, Athens 1977; 384.

15. Homer. Odyssey $\Sigma$ ' 95-9.

16. Mouratidis I. History of physical education (with elements of philosophy). K. Christodoulidis, Thessalonica 1990; 69. 17. Homer. Iliad $\psi^{\prime}$ 669-99.

18. Homer, lliad $\psi$ ' 392-7.

19. Homer, Odyssey $\Sigma^{\prime}$ 95-9.

20. Philostratus, Gymnastics, 9. 